\title{
PERSEPSI WISATAWAN TERHADAP DAYA TARIK EKOWISATA BAHARI PANTAI ENABARA, KABUPATEN ENDE, PROVINSI NUSA TENGGARA TIMUR
}

\author{
Novita Masi Dari Tani MD \\ Email: novita@poltekelbajo.ac.id \\ Politeknik eLBajo Commodus
}

\begin{abstract}
Ende Regency has a huge potential to be developed into a tourist attraction. One of them is the marine tourism attraction located in Aewora Village, Maurole District, namely Pantai Enabara. The beach has not been developed because of the lack of government attention and the low level of tourism human resources of the local community. This study aims to determine the role of stakeholders, to know the perceptions of the local community and tourists, and to conduct a strategic development of tourist attractions. The research used a qualitative method with Likert scale assisted. The data were collected by observation, interview, questionnaire, and documentation study. The number of respondents in the data collection of 20 respondents selected incidentally. The concept used in research is the concept of tourist attraction, marine ecotourism, and perception. The results showed that tourists are very enthusiastic to welcome the proposal to make Enabara Beach a tourist destination. In terms of tourists, tourists realize that Enabara Beach has a very attractive appeal and tourists also agree if the beach is managed based on the principles of eco-tourism. In supporting the maritime tourism development strategy based on ecotourism, active participation from the community, Local Government, and coordination of all stakeholders are needed to improve the quality of service and tourism attractions, accessibility, facilities, and institutions.
\end{abstract}

Keywords: Tourist Attraction, Marine Ecotourism, Tourist Perception

\begin{abstract}
Abstrak
Potensi wisata di Kabupaten Ende sangat tinggi sehingga dapat dikembangkan menjadi daya tarik wisata. Salah satunya adalah daya tarik wisata bahari yang dimiliki Kabupaten Ende adalah Pantai Enabara yang terletak di Desa Aewora, Kecamatan Maurole. Pantai tersebut belum dikembangkan karena belum adanya perhatian pemerintah serta rendahnya SDM pariwisata masyarakat setempat. Penelitian ini bertujuan untuk mengetahui persepsi wisatawan, dan menghasilkan strategi pegembangan daya tarik wisata. Penelitian menggunakan metode kualitatif dengan alat
\end{abstract}


analisis skala likert. Observasi, wawancara, kuisioner, dan studi dokumentasi digunakan sebagai alat pengumpulan data dalam penelitian ini. Jumlah responden dalam pengumpulan data sebanyak 20 orang yang dipilih secara kebetulan. Konsep yang digunakan dalam penelitian yaitu konsep daya tarik wisata ekowisata bahari, dan persepsi wisatawan. Hasil penelitian menunjukkan bahwa wisatawan sangat antusias menyambut usulan untuk menjadikan Pantai Enabara sebagai destinasi wisata. Wisatawan menyadari bahwa Pantai Enabara memiliki daya tarik yang sangat memikat dan wisatawan juga setuju apabila pantai Enabara dikelola berdasarkan prinsip-prinsip ekowisata. Dalam mendukung strategi pengembangan wisata bahari berbasis ekowisata dibutuhkan partisipasi aktif dari masyarakat, Pemerintah Daerah, dan koordinasi seluruh stakeholder untuk meningkatkan kualitas pelayanan dan atraksi wisata, aksesibilitas, fasilitas, dan kelembagaan.

Kata Kunci: Daya Tarik Wisata, Ekowisata Bahari, Persepsi Wisatawan

\section{Pendahuluan}

Pariwisata merupakan salah satu sektor yang diandalkan oleh Pemerintah Indonesia untuk meningkatkan perekonomian negara saat ini. Pemerintah Indonesia telah menetapkan lima sektor prioritas dalam Rencana Pembangunan Jangka Menengah (RJPM) tahun 2015-2019, yakni pertanian, perikanan dan kelautan, energi, industri, dan pariwisata. Menurut Presiden Jokowi yang dikutip dari Swa.co.id, pariwisata menjadi kunci untuk menempuh pembangunan ekonomi jangka pendek.

Pemerintah Kabupaten Ende menanggapi program pemerintah pusat dengan mengembangkan beberapa daya tarik wisata di Kabupaten Ende. Hal ini dilakukan dengan menetapkan Rencana Induk Pembangunan Kepariwisataan Daerah (Ripparda) Kabupaten Ende Tahun 2014-2034. Dalam perencanaan tersebut, sasaran yang hendak dicapai oleh Pemerintah Kabupaten Ende diantaranya adalah: peningkatan jumlah wisatawan mancanegara; peningkatan jumlah pergerakan wisatawan nusantara; peningkatan jumlah penerimaan devisa dari wisatawan mancanegara; peningkatan jumlah pengeluaran wisatawan nusantara; peningkatan lama 
tinggal wisatawan; dan peningkatan jumlah produk domestik bruto dan Pendapatan Asli Daerah (PAD) Kabupaten Ende.

Kabupaten Ende memiliki empat jenis wisata, yakni wisata alam, wisata budaya, wisata sejarah, dan wisata minat khusus. Namun yang terjadi selama ini adalah wisatawan hanya mengetahui wisata danau tiga warna Kelimutu, sehingga wisatawan hanya berkunjung ke Kelimutu. Padahal di sekitar danau kelimutu terdapat beberapa destinasi yang sangat menarik, seperti jajaran pantai-pantai yang ada di wilayah Kabupaten Ende. Ada enam daya tarik wisata bahari yang telah dipromosikan di Kabupaten Ende yakni Pantai Penggajawa, Pantai Enabara, Pantai Mbuu, Pantai Jaga Po, Pantai Maukaro, dan Pantai Ria.

Wisata bahari di Pantai Enabara tampaknya berada pada fase involvement. Berdasarkan teori life cycle yang diajukan oleh Butler, fase involvement ditandai dengan meningkatnya pengunjung yang mendorong penduduk lokal menawarkan fasilitas secara eksklusif kepada pengunjung. Kontak dengan penduduk lokal tinggi dan beberapa penduduk lokal mulai menyesuaikan pola sosial yang sudah terbentuk lama untuk mengakomodasikan perubahan kondisi ekonomi akibat keberadaan wisatawan, misalnya dalam menyediakan makanan bagi wisatawan. Pada tahap ini, destinasi wisata mulai dipromosikan, dan telah terdeteksi pasar utama wisatawan. Pada fase ini mulai terjadi tekanan terhadap pemerintah untuk menyediakan fasilitas penunjang bagi wisatawan.

Pergeseran dalam minat wisatawan dari kecenderungan untuk mengunjungi objek yang turistik dan buatan ke daerah-daerah yang masih alamiah dengan tujuan-tujuan khusus yang telah ditapkan sebelumnya menjadi perhatian Perserikatan Bangsa-Bangsa yang kemudian menetapkan tahun 2012 sebagi tahun ekowisata. Tren kegiatan ekowisata memberikan peluang bagi Kabupaten Ende yang memiliki lanskap yang masih alami untuk mengembangkan potensinya sebagai destinasi 
ekowisata. Untuk itu perlu diketahui persepsi wisatawan untuk mengformulasikan sebuah model pengembangan baru sehingga wisatawan mengetahui daya tarik wisata bahari yang dimiliki oleh Kabupaten Ende dan demi berkelanjutan daya tarik tersebut.

\section{Tinjauan Pustaka}

\subsection{Daya Tarik Wisata}

Menurut undang-Undang RI Nomor 10 Tahun 2009 tentang kepariwisataan, daya tarik wisata adalah segala sesuatu yang memiliki keunikan, keindahan, dan nilai yang berupa keanekaragaman kekayaan alam, budaya, dan hasil buatan manusia yang menjadi sasaran atau tujuan kunjungan wisatawan. Keunikan, keindahan dan nilai tersebut yang menjadi faktor penyebab seseorang mengunjungi daya Tarik wisata.

Menurut Cooper dkk dalam Sugiama (2014), sebuah destinasi wisata terdiri dari kombinasi empat komponen kepariwisataan, di antaranya:

1. Attraction merupakan suatu objek yang memiliki daya tarik bagi seseorang untuk menikmati/menyaksikan objek tersebut.

2. Access mencakup fasilitas prasarana dan sarana yang memungkinkan wisatawan dapat menjangkau atau sampai ke destinasi wisatanya. Beberapa faktor dalam komponen aksesibilitas adalah fasilitas local transport, dan transport terminals.

3. Amenities meliputi beragam fasilitas untuk memenuhi kebutuhan akomodasi, penyediaan makanan dan minuman, tempat hiburan, tempat-tempat perbelanjaan, dan layanan lainnya seperti kebutuhan penunjang untuk kesehatan, perbankan, dan jaminan keamanan.

4. Ancillary services, merupakan keberadaan berbagai organisasi yang ditujukan untuk memfasilitasi dan mendorong terus makin berkembangnya kepariwisataan di destinasi bersangkutan. 
Jadi, yang dimaksud dengan pengembangan daya tarik wisata dalam penelitian ini adalah daya tarik wisata Pantai Enabara yang ada di Kabupaten Ende, yang nanti dalam perkembangannya memenuhi unsur $4 \mathrm{~A}$.

\subsection{Ekowisata Bahari}

Wisata bahari merupakan jenis wisata yang memanfaatkan potensi wilayah lingkungan pesisir dan lautan secara langsung dan tidak langsung, berupa berenang, snorkeling, menyelam, cannoing, dan memancing. Wisata bahari tidak dapat dilepaskan dari kegiatan wisata alam. Kegiatan ini sering disebut juga kegiatan wisata pantai yang memanfaatkan potensi lingkungan pantai sebagai daya tarik utama. Wisata bahari antara satu tempat dan tempat lain dapat berbeda, tergantung karakteristik pantai dan lingkungan sosial budaya di tempat yang bersangkutan.

Menurut Fandeli (2002), daya tarik wisata bahari terdiri atas dua bagian yaitu bentangan laut dan bentang darat. Selanjutnya Fandeli mengklasifikasikan tiga jenis kegiatan wisata bahari, yaitu: (1) surface activities, merupakan aktivitas wisata yang dilakukan di atas permukaan air, (2) contact activities, merupakan aktivitas yang dilakukan wisatawan dengan melakukan kontak air, dan (3) littoral activities, merupakan kegiatan berwisata yang dilakukan di darat.

Kegiatan ekowisata merupakan bentuk wisata yang dikelola dengan pendekatan konservasi. Selain konservasi (lingkungan), kegiatan tersebut juga harus mempertimbangkan faktor ekonomi dan sosial budaya agar berkelanjutan.

Dalam penelitian ini, yang dimaksudkan dengan ekowisata (bahari) adalah salah satu sektor yang akan dikembangkan sesuai dengan hasil penelitian Mithe sebelumnya. Ekowisata bahari tersebut meliputi (1) 
Batu Penggajawa, (2) Pantai Pasir Putih Enabara Maurole, (3) Pantai Mbuu, dan (4) Sunset Pantai Ria Ende.

\subsection{Persepsi}

Persepsi adalah proses seseorang menyeleksi, mengorganisasikan, dan menginterpretasikan sesuatu agar dapat memberikan arti terhadap lingkungan. Ada dua faktor yang mempengaruhi persepsi yakni faktor personal dan faktor struktural. Faktor personal antara lain adalah proses belajar, motif, dan kebutuhan, sedangkan faktor struktural meliputi lingkungan, nilai sosial dalam masyarakat (Rangkuti, 2002).

Empat tahap pemrosesan informasi dalam pembentukan persepsi (Kreitner dan Kinicki, 2001) adalah sebagai berikut:

1. Tahap perhatian selektif (selective attention), yang merupakan proses timbulnya kesadaran akan sesuatu atau seseorang

2. Tahap interpretasi dan penyederhanaan (encoding and simplification), yaitu proses interpretasi atau translasi informasi menjadi representasi mental

3. Tahap penyimpanan dan pengulangan (storage and retention), yaitu tahap penyimpanan informasi dalam memori jangka panjang

4. Tahap penarikan informasi dan pemberian respon (retrieval and response), yang dilakukan pada saat seseorang membuat pertimbangan dan mengambil keputusan.

Pada tahap encoding and simplification, seseorang dapat menghasilkan interpretasi yang berbeda dengan orang lain, walaupun kejadian yang dialami merupakan kejadian yang sama. Menurut Kreitner dan Kinicki (2001), perbedaan interpretasi ini dapat disebabkan oleh: (1) perbedaan informasi dalam skema yang digunakan untuk interpretasi, (2) pengaruh mood dan emosi, (3) menerapkan kategori kognitif terkini, serta (4) perbedaan individual. 
Persepsi dapat terjadi kapan saja, dimana saja dan dialami oleh siapa saja. Persepsi mencakup penerimaan stimulus, penggorganisasian stimulus, penafsiaran stimulus yang telah diorganisasikan dengan cara mempengaruhi perilaku dan membentuk sikap (Rangkuti, 2002).

Persepsi sangat berpengaruh terhadap perilaku manusia. Dalam penelitian ini, Teori Persepsi digunakan untuk mengetahui persepsi masyarakat dan wisatawan mengenai pengembangan daya tarik wisata bahari di Kabupaten Ende

\section{Metode}

Analisis Deskriptif Kualitatif digunakan dalam penelitian ini. Data dikumpulkan dengan cara pengamatan langsung (observasi), dokumentasi, wawancara, penyebaran angket (questioner), dan studi kepustakaan. Populasi yang digunakan dalam penelitian ini adalah semua wisatawan yang berkunjung ke Daya Tarik Wisata Pantai Enabara. Accidental sampling digunakan dalam penelitian ini.

Accidental Sampling adalah teknik pengambilan sampel dengan mengambil beberapa orang yang secara tidak sengaja bertemu di lokasi penelitian. Dalam penelitian ini jumlah populasinya belum diketahui karena tidak ada pencatatan jumlah wisatawan bahari secara komprehensif ke empat daya tarik wisata Pantai Enabara, maka ditetapkan 20 wisatawan di lokasi penelitian. Wisatawan akan diberikan kuisioner di masing-masing lokasi penelitian. Pendapat wisatawan ini diperlukan untuk mengetahui persepsi wisatawan mengenai daya tarik wisata Pantai Enabara serta dalam penyusunan paket wisata yang hendak ditawarkan.

Penelitian ini dilakukan di Pantai Enabara, Kabupaten Ende, Provinsi Nusa Tenggara Timur. Terdapat beberapa pertimbangan mengenai dipilihnya Pantai Enabara sebagai lokasi penelitian, yaitu: selain Taman Nasional Kelimutu, masih ada daya tarik wisata lainnya yang bisa 
dikunjungi di Kabupaten Ende; jumlah kunjungan wisatawan relatif meningkat tetapi tidak diikuti dengan jumlah wisatawan yang menginap dan lama tinggal wisatawan di Kabupaten Ende; dan Kabupaten Ende memiliki potensi wisata bahari yang indah tetapi belum dikembangkan dengan baik.

\section{Hasil dan Pembahasan}

Pengisian kuisioner yang telah dilaksanakan dengan jumlah responden yang terdiri dari 20 orang. Responden merupakan wisatawan yang dimintai kesediaannya dalam mengisi kuisioner yang terkait dengan penelitian ini, masing-masing memiliki jawaban yang berbeda tetapi pada dasarnya wisatawan sangat setuju apabila Pantai Enabara dikembangkan menjadi destinasi wisata dan dikelola berdasarkan prinsip-prinsip ekowisata karena prinsip ini menjamin keberlanjutan sumber daya alam yang ada. Berikut data disajikan pada Tabel 1. 
Tabel 1.

Distribusi Penilaian Persepsi Wisatawan Terhadap Pengembangan Daya Tarik

Wisata Pantai Enabara Di Kabupaten Ende

\begin{tabular}{|c|c|c|c|c|c|c|c|c|c|c|c|c|}
\hline \multirow{2}{*}{ Objek Persepsi } & \multicolumn{2}{|c|}{ SS } & \multicolumn{2}{|c|}{ S } & \multicolumn{2}{|c|}{$\mathrm{N}$} & \multicolumn{2}{|c|}{ TS } & \multicolumn{2}{|c|}{ STS } & \multirow{2}{*}{ Total Skor } & \multirow{2}{*}{$\begin{array}{c}\text { Persepsi } \\
\text { Wisatawan }\end{array}$} \\
\hline & JO & $S$ & $\mathrm{JO}$ & $S$ & $\mathrm{JO}$ & $\mathrm{S}$ & $\mathrm{JO}$ & $\mathrm{S}$ & JO & S & & \\
\hline $\begin{array}{l}\text { Kondisi Pantai Yang } \\
\text { Baik }\end{array}$ & 10 & 50 & 7 & 28 & 3 & 9 & - & - & - & - & $87 / 20=4,35$ & Sangat setuju \\
\hline Pantai Yang Bersih & 3 & 15 & 4 & 16 & 7 & 21 & 5 & 10 & 1 & 1 & $63 / 20=3,15$ & Netral \\
\hline $\begin{array}{l}\text { Akses Yang Baik } \\
\text { Menuju Pantai Enabara }\end{array}$ & 6 & 30 & 5 & 20 & 4 & 12 & 5 & 10 & - & - & $72 / 20=3,5$ & Setuju \\
\hline $\begin{array}{l}\text { Kemudahan Dalam } \\
\text { Memperoleh Informasi }\end{array}$ & 5 & 25 & 12 & 48 & 3 & 9 & - & - & - & - & $82 / 20=4,1$ & Setuju \\
\hline $\begin{array}{l}\text { Fasilitas Pendukung } \\
\text { Yang Memadai }\end{array}$ & - & - & 1 & 4 & 1 & 3 & 14 & 28 & 4 & 4 & $39 / 20=1,95$ & Tidak setuju \\
\hline $\begin{array}{l}\text { Masyarakat Yang } \\
\text { Ramah }\end{array}$ & 9 & 45 & 11 & 44 & - & - & - & - & - & - & $89 / 20=4,45$ & Sangat setuju \\
\hline $\begin{array}{l}\text { SDM Pengelola Yang } \\
\text { Memadai }\end{array}$ & - & - & 2 & 8 & 3 & 9 & 7 & 14 & 8 & 8 & $39 / 20=1,95$ & Tidak setuju \\
\hline $\begin{array}{l}\text { Perlunya Keterlibatan } \\
\text { LSM }\end{array}$ & 10 & 50 & 7 & 28 & - & - & 3 & 6 & - & - & $84 / 20=4,1$ & Setuju \\
\hline $\begin{array}{l}\text { Dukungan Untuk } \\
\text { Dikembangkan Menjadi } \\
\text { Destinasi Wisata }\end{array}$ & 18 & 90 & 2 & 8 & - & - & - & - & - & - & $98 / 20=4,9$ & Sangat setuju \\
\hline $\begin{array}{l}\text { Rencana Pengelolaan } \\
\text { Yang Didasarkan Pada } \\
\text { Prinsip-Prinsip } \\
\text { Ekowisata }\end{array}$ & 13 & 65 & 7 & 28 & - & - & - & - & - & - & $93 / 20=4,65$ & Sangat setuju \\
\hline $\begin{array}{l}\text { Ketertarikan Untuk } \\
\text { Mengetahui Lebih } \\
\text { Dalam Tentang Produk } \\
\text { Ekowisata }\end{array}$ & 13 & 65 & 7 & 28 & - & - & - & - & - & - & $93 / 20=4,65$ & Sangat setuju \\
\hline $\begin{array}{l}\text { Ketertarikan Untuk } \\
\text { Menginap Di Rumah } \\
\text { Masyarakat Setempat }\end{array}$ & 8 & 40 & 5 & 20 & 4 & 12 & 3 & 6 & - & - & $78 / 20=3,9$ & Setuju \\
\hline $\begin{array}{l}\text { Ketertarikan Untuk } \\
\text { Melakukan Kegiatan } \\
\text { Ekowisata }\end{array}$ & 11 & 55 & 8 & 32 & 1 & 3 & - & - & - & - & $80 / 40=20$ & Setuju \\
\hline $\begin{array}{l}\text { Kesediaan Jika } \\
\text { Dibebankan Biaya } \\
\text { Untuk Upaya } \\
\text { Konservasi dan } \\
\text { Pemberdayaan } \\
\text { Masyarakat }\end{array}$ & 6 & 30 & 10 & 40 & 3 & 3 & 1 & 2 & - & - & $81 / 20=4,05$ & Setuju \\
\hline
\end{tabular}

Sumber: Hasil Olahan Data, 2018

Keterangan: J(O): Jumlah Orang (Jumlah Responden Yang Mengisi Kuisioner)

Total Skor (Secara Keseluruhan) : Total Skor (Per Item)

Jumlah Responden 


\section{a. Persepsi Wisatawan Terhadap Kondisi Pantai Yang Baik}

Berdasarkan Tabel 1 dapat dilihat bahwa persepsi masyarakat terhadap kondisi pantai yang baik menunjukkan sikap sangat setuju. 50\% wisatawan menyatakan sangat setuju dan $35 \%$ setuju terhadap hal tersebut. Menurut wisatawan, kondisi Pantai Enabara sangat baik. Hal ini bisa terjadi mengingat Pantai Enabara yang masih sangat alami, masih terdapat banyak pohon yang dapat digunakan untuk berteduh juga atraksi-atraksi alami yang sangat memikat hati.

Pantai Enabara sebagai daya tarik wisata sangat sesuai dari segi atraksi wisata karena kondisi pantai yang baik. Di sisi lain tidak terdapat wisatawan yang menyatakan persepsi tidak setuju. Sebanyak 15\% wisatawan menyatakan sikap netral. Hal tersebut ditengarai karena letaknya yang terlalu mepet dengan jalan raya sehingga sempadan pantainya menjadi sangat sempit ketika terjadi pasang.

b. Persepsi Wisatawan Terhadap Pantai Yang Bersih

Berdasarkan Tabel 1 dapat dilihat bahwa persepsi wisatawan terhadap pantai yang bersih menunjukkan sikap netral. 15\% wisatawan sangat setuju bahwa Pantai Enabara sangat bersih dan 20\% setuju terhadap hal tersebut. Di sisi lain ada wisatawan yang menyatakan persepsi tidak setuju. 35\% menyatakan persepsi netral, 25\% menyatakan persepsi tidak setuju dan 5 menyatakan sangat tidak setuju terhadap hal tersebut. Hal ini wajar karena dalam beberapa kali pengamatan penulis, penulis merasakan hal yang sama. Terkadang pantainya sangat bersih sampai tidak menyisakan satu helai sampah pun, di lain waktu, sampahnya begitu banyak, berserakan dimana-dimana. Kebanyakan bungkus nasi dan gelas air mineral.

Berdasarkan wawancara dengan warga, warga mengatakan bahwa sampah-sampah itu hadir ketika serombongan wisatawan meninggalkan tempat itu, sedangkan keadaan bersih itu tercipta karena masyarakat 
sendiri memiliki kesadaran untuk menjaga lingkungan pantai, sehingga masyarakat setempat menyapu, mengumpulkan sampah dan membersihkannya secara sukarela. Banyak wisatawan yang belum menyadari akan kebersihan lingkungan, khususnya pantai, sehingga perlu disediakan tempat sampah di titik-titik tertentu di sepanjang garis pantai. Selain itu, perlu juga dipasang papan-papan larangan untuk membuang sampah di titik-titik yang dirasa perlu agar wisatawan yang sering membuang sampah sembarangan merasa tertampar.

c. Persepsi Masyarakat Terhadap Akses Yang Baik Menuju Pantai Enabara

Berdasarkan Tabel 1 dapat dilihat bahwa persepsi wisatawan terhadap akses yang baik menuju Pantai Enabara menunjukkan persepsi setuju. Hal tersebut terlihat sebanyak $30 \%$ wisatawan menyatakan sangat setuju dan 25\% menyatakan setuju terhadap hal tersebut. Pantai Enabara sebagai daya tarik wisata sangat sesuai dari letaknya yang strategis. Pantai Enabara terletak di jalur Pantai Utara Pulau Flores. Jalur ini menghubungkan tiga kabupaten di Pulau Flores, yakni Kabupaten Nagekeo, Ende, dan Sikka.

Di sisi lain terdapat beberapa masyarakat yang menyatakan sikap tidak setuju. Sebanyak 20\% masyarakat menjawab netral dan 25\% menjawab tidak setuju. Pengunjung yang melewati jalan sepanjang Kecamatan Detusoko sampai Kecamatan Wewaria menyatakan bahwa aksesnya sangat buruk. Menurut warga setempat, ketika banjir melanda, jalan di Tendaleo yang sudah putus akan digenangi oleh air sehingga tidak bisa dilewati oleh kendaraan apapun, sedangkan di hari-hari biasa walaupun tidak turun hujan, kendaraan tetap harus melewati jalan yang menjorok ke dalam membentuk sungai kecil sehingga pengendara kendaraan bermotor yang belum terbiasa melewati jalanan serupa harus 
melepas sepatu agar tidak basah karena kakinya harus bertumpuh pada batu di kanan kirinya sebab jalanan di dalam lubang tidak rata.

d. Persepsi Wisatawan Terhadap Kemudahan Dalam Memperoleh Informasi

Berdasarkan Tabel 1 dapat dilihat bahwa persepsi wisatawan terhadap kemudahan dalam memperoleh informasi menunjukkan persepsi setuju. Hal tersebut dilihat dari sebanyak $25 \%$ wisatawan menjawab sangat setuju dan 60\% menjawab setuju. Pantai Enabara sangat terkenal di kalangan wisatawan lokal, namun tidak demikian halnya untuk wisatawan nusantara dan macanegara. Sebagai salah satu daya tarik wisata di Kabupaten Ende, Pantai Enabara harus dikenal oleh dunia agar semakin berkembang dan membuka lapangan kerja baru sehingga dapat memberi kontribusi positif bagi masyarakat setempat.

Di sisi lain terdapat beberapa wisatawan yang menyatakan sikap tidak setuju. Sebanyak 15\% masyarakat menjawab ragu-ragu. Hal tersebut disebabkan oleh tidak adanya promosi yang gencar dari dinas pariwisata Kabupaten Ende akan Pantai Enabara. Mengenai informasi yang diperoleh mengenai Pantai Enabara, 16 responden mengaku bahwa informasi mengenai Pantai Enabara diperoleh dari teman, sedangkan 4 lainnya memperolehnya dari saudara, media sosial dan biro perjalanan. Hal ini menunjukkan bahwa Words of Mouth (WoM) memiliki peranan yang besar dalam mempromosikan Pantai Enabara. Ketika memutuskan untuk berkunjung ke Pantai Enabara, sebagian besar wisatawan melakukan kunjungan dengan teman, yakni sebanyak 14 orang sedangkan dengan keluarga sebanyak 5 orang. Tak satu orang pun pengunjung yang melakukan kunjungan dengan bantuan biro perjalanan. Hal ini menunjukkan bahwa tour operator belum melirik Pantai Enabara sebagai destinasi wisata yang potensial, yang dapat dijual dan belum adanya promosi. 
Berdasarkan kuisioner juga, dari 20 responden 15 diantaranya berasal dari Kabupaten Ende dan hanya 5 orang berasal dari luar Kabupaten Ende, yaitu 2 orang dari Maumere, 2 orang dari Mbay, dan 1 orang dari Adonara. Akan tetapi menurut Bapak Felix, ada wisatatawan yang berasal dari luar NTT, bahkan dari luar negeri yang berkunjungn ke Pantai Enabara. Lebih jauh lagi menurutnya ada wisman yang melakukan camping di pantai ini dan menikmati Pantai Enabara ini. Selama peneliti melakukan penelitian di Pantai Enabara tidak ditemukan wisatawan mancanegara. Hal ini ditengarai karena promosi yang kurang dari Pemerintah Daerah Kabupaten Ende.

e. Persepsi Masyarakat Terhadap Fasilitas Pendukung Yang Memadai

Berdasarkan Tabel 1 dapat dilihat bahwa persepsi masyarakat terhadap fasilitas pendukung menunjukkan persepsi tidak setuju. Hal tersebut terlihat dari jawaban responden. Empat wisatawan yang menjawab sangat tidak setuju, 14 wisatawan menyatakan tidak setuju, dan satu wisatawan yang menjawab netral terhadap hal tersebut. Sikap tidak setuju tersebut beralasan karena tidak ada satupun fasilitas yang disediakan bagi pengunjung di sana, bahkan badan pengelola pun tidak ada. Kamar mandi serta toilet umum pun tidak ada, sehingga ketika ada wisatawan yang melakukan aktivitas air, wisatawan harus meminjam kamar mandi milik warga. Satu wisatawan menyatakan setuju jika fasilitas pendukung di Pantai Enabara memadai. Hal tersebut ditengarai karena terdapat kios kecil serta bale-bale (tempat peristirahatan) di pinggir jalan dekat bibir Pantai milik warga yang berjualan di sana.

Berdasarkan tujuan berkunjung, semuanya menjawab bahwa tujuan berkunjung adalah untuk berekreasi, sementara kegiatan yang dilakukan hanyalah sebatas menikmati pemandangan pantai. Menurut pengamatan juga begitu adanya. Selama berekreasi tidak ada satupun wisatawan yang terlihat melakukan aktivitas air, seperti mandi/berenang 
dan aktivitas snorkeling, padahal air lautnya sangat tenang, bersih dan juga jernih. Selain itu bawah lautnya juga cukup indah karena banyak ikan beraneka jenis dan warna hidup disana, walaupun terumbu karangnya banyak yang sudah rusak akibat oknum yang tidak bertanggungjawab. Hal ini ditengarai disebabkan oleh tidak adanya fasilitas kamar mandi yang bisa digunakan oleh wisatawan setelah melakukan aktivitas air tersebut. Oleh sebab itu sangat perlu bagi masyarakat setempat untuk membangun beberapa fasilitas pokok yang akan mendukung berkembangnya Pantai Enabara sebagai destinasi wisata, seperti toilet, kamar mandi, dan lain sebagainya. Namun sebelum melangkah ke fasilitas-fasilitas tersebut, sebaiknya masyarakat terlebih dahulu membentuk badan pengelola Pantai Enabara agar lebih terorganisir.

\section{f. Persepsi Wisatawan Terhadap Masyarakat Yang Ramah}

Berdasarkan Tabel 1 dapat dilihat bahwa persepsi wisatawan terhadap masyarakat yang ramah menunjukkan persepsi sangat setuju. $45 \%$ wisatawan menjawab sangat setuju dan 55\% menjawab setuju terhadap hal tersebut. Masyarakat di sana sangat ramah. Masyarakat sangat terbuka terhadap wisatawan yang datang karena masyarakat sadar bahwa wisatawan, secara ekonomi dapat membawa dampak postif.

\section{g. Persepsi Wisatawan Terhadap SDM Pengelola Yang Memadai}

Berdasarkan Tabel 1 dapat dilihat bahwa persepsi wisatawan terhadap SDM pengelola yang memadai menunjukkan persepsi tidak setuju. Hanya 10\% wisatawan menjawab setuju, sedangkan 15\% menjawab netral, $35 \%$ menjawab tidak setuju, dan $40 \%$ menjawab sangat tidak setuju. Di tempat ini belum ada pengelola yang sudah diresmikan secara pasti. Hanya terdapat satu lapak dagang yang dikelola oleh dua keluarga kakak beradik. Tidak dikenakan biaya retribusi juga untuk masuk ke daya tarik wisata Pantai Enabara. 


\section{h. Persepsi Wisatawan Terhadap Perlunya Keterlibatan LSM}

Berdasarkan Tabel 1 dapat dilihat bahwa sikap wisatawan terhadap perlunya keterlibatan LSM menunjukkan persepsi setuju. Hal tersebut terlihat dari 50\% wisatawan menjawab sangat setuju dan $35 \%$ menjawab setuju. Di sini wisatawan menilai bahwa LSM sangat dibutuhkan mengingat SDM yang mampu mengelola Pantai Enabara secara profesional tidak ada.

Di sisi lain ada wisatawan yang menyatakan sikap tidak setuju. Hal tersebut terlihat dari $15 \%$ wisatawan yang menjawab netral. Hal tersebut disebabkan oleh kekhawatiran akan ketidakseriusan LSM dalam menangani daya tarik wisata Pantai Enabara.

i. Persepsi Terhadap Dukungan Untuk Dikembangkan Menjadi

Destinasi Wisata

Berdasarkan Tabel 1 dapat dilihat bahwa persepsi wisatawan terhadap dukungan untuk dikembangkan menjadi destinasi wisata menunjukkan persepsi sangat setuju. Hal tersebut terlihat dari $90 \%$ wisatawan menyatakan sangat setuju dan $10 \%$ menyatakan setuju. Hal ini menunjukkan bahwa mereka sangat menikmati keindahan dan kenyamanan di daya tarik wisata Pantai Enabara. Hal ini ditunjukkan pula oleh jawaban dari 20 wisatawan bahwa hanya empat orang wisatawan yang dijadikan responden yang baru pertama kali berkunjung ke Pantai Enabara, sedangkan 16 lainnya atau 80\%nya sudah berkunjung lebih dari 2 kali. Hal tersebut menunjukkan bahwa wisatawan sangat menikmati keindahan yang disajikan oleh Pantai Enabara, padahal saat ini belum terkelola dengan serius. 
j. Persepsi Terhadap Rencana Pengelolaan Yang Didasarkan Pada Prinsip-Prinsip Ekowisata

Berdasarkan Tabel 1 dapat dilihat bahwa persepsi masyarakat terhadap pengelolaan yang didasarkan pada prinsip-prinsip ekowisata menunjukkan persepsi sangat setuju. Hal tersebut terlihat dari $65 \%$ wisatawan menyatakan sangat setuju dan 35\% menyatakan setuju. LSM diharapkan mampu membawa Pantai Enabara ke arah yang lebih baik. Wisatawan sangat setuju apabila Pantai Enabara dikelola berdasarkan prinsip-prinsip ekowisata karena wisatawan juga sangat tertarik untuk mengetahui lebih dalam tentang produk ekowisata di enabara dan sangat tertarik untuk melakukan kegiatan ekowisata di tempat ini. Wisatawan juga tertarik untuk menginap di rumah warga apabila suatu saat rumah-rumah warga dipersiapkan untuk menjadi homestay bagi wisatawan yang hendak berekowisata di tempat ini. Sedangkan ketika ditanyai mengenai ketersediaan wisatawan apabila dibebankan biaya untuk upaya konservasi dan pemberdayaan masyarakat di wilayah pantai, wisatawan menyatakan bersedia. Dukungan wisatawan terhadap pengelolaan berdasarkan prinsipprinsip ekowisata di Pantai Enabara didasari pada bentuk kepedulian terhadap kondisi pantai tersebut. Faktor kedua yang mendasari dukungan masyarakat adalah terletak pada kebutuhan ekonomi dan menambah lapangan kerja.

Mengenai keamanan, 19 orang merasa aman karena tidak ada yang mengganggu, jauh dari pemukiman, tidak terganggu dengan kebisingan kendaraan di laut, masyarakat yang ramah dan baik serta jauh dari kericuhan. Sementara itu ada satu yang merasa tidak aman karena karena setiap pengunjung yang datang tidak pernah mentaati peraturan, selalu membuat keributan, mabuk-mabukan. Mengenai keadaan ini benar adanya. Yang mabuk-mabukkan di Pantai Enabara kebanyakan merupakan warga kampung di sekitar desa aewora. Penulis sempat bertanya kepada 
wisatawan saat itu. Kedepannya, jika ada pengelola, semoga pengelola bisa menindak tegas perbuatan tidak menyenangkan ini, sehingga pengunjung bisa tempat tersebut.

\section{Simpulan dan Rekomendasi}

Pantai Enabara memiliki daya tarik yang sangat memikat, akan tetapi belum dikelola secara maksimal. Wisatawan sangat antusias menyambut usulan untuk menjadikan Pantai Enabara sebagai destinasi wisata. Menurut persepsi wisatawan, daya tarik wisata tersebut secara alamiah masih murni dan berpotensi untuk dikembangkan menjadi daya tarik ekowisata bahari.

Apabila dikelola secara maksimal, daya tarik wisata tersebut dapat menjadi destinasi wisata alternatif bagi wisatawan saat berkunjung ke Kabupaten Ende. Oleh karena itu, dapat mendatangkan keuntungan ekonomi yang besar bagi masyarakat yang ada di sekitar destinasi wisata Selain masyarakat, Pemerintah Daerah Kabupaten Ende juga memperoleh keuntungan dari perkembangan Daya Tarik Wisata Pantai Enabara dalam bentuk peningkatan Pendapatan Asli Daerah (PAD) Kabupaten Ende.

\section{Daftar Pustaka}

Anonim. 2009. Undang-undang RI No. 10 Tahun 2009 tentang Kepariwisataan.

Anonim. 2014. Peraturan Daerah Kabupaten Ende Nomor 11 Tahun 2014 Tentang Rencana Pembangunan Jangka Menengah Daerah Kabupaten Ende Tahun 2014 - 2019.

Anonim. 2011. Dinas Kebudayaan dan Pariwisata Kabupaten Ende, Profil Pariwisata Kabupaten Ende, Ende

Anonim. 2017. Lima Sektor Prioritas Pembangunan Ekonomi Jokowi-JK. https://swa.co.id/swa/trends/management/lima-sektor-prioritaspembangunan- ekonomi

Butler, R.W. 2011. Tourism Area Life Cycle. Oxford: Goodfellow Publishers Ltd.

Kreitner R, dan Kinicki, A. 2001. Organizational Behavior. $5^{\text {th }}$ Edition. Boston: McGraw-Hill companies. 
Rangkuti, F. 2002. Measuring Customer Satisfaction. Jakarta: PT Gramedia Pustaka Utama.

Sugiama, G. 2014. Manajemen Aset Pariwisata: Pelayanan Berkualitas agar Wisatawan Puas dan Loyal. Bandung: Guardaya Intimarta.

Sugiyono, 2013. Metode Penelitian Kualitatif. Yogyakarta: Alfabeta.

\section{Profil Penulis}

Novita Masi Dari Tani MD adalah dosen di Politeknik eLBajo Commodus Labuan Bajo. Dapat lebih lanjut dihubungi melalui surel: novita@poltekelbajo.ac.id 